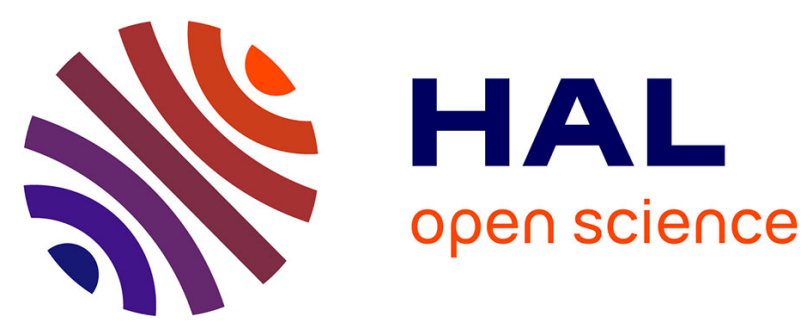

\title{
Seasonal variation of pollution biomarkers to assess the impact on health status of juvenile Pacific oysters Crassostrea gigas exposed in situ
}

\author{
Andrea Luna Acosta, Paco Bustamante, Joachim Godefroy, Ingrid
} Fruitier-Arnaudin, Hélène Thomas-Guyon

\section{To cite this version:}

Andrea Luna Acosta, Paco Bustamante, Joachim Godefroy, Ingrid Fruitier-Arnaudin, Hélène ThomasGuyon. Seasonal variation of pollution biomarkers to assess the impact on health status of juvenile Pacific oysters Crassostrea gigas exposed in situ. Environmental Science and Pollution Research, 2010, 17 (4), pp.999-1008. 10.1007/s11356-009-0287-1 . hal-00483862

\section{HAL Id: hal-00483862 https://hal.science/hal-00483862}

Submitted on 17 May 2010

HAL is a multi-disciplinary open access archive for the deposit and dissemination of scientific research documents, whether they are published or not. The documents may come from teaching and research institutions in France or abroad, or from public or private research centers.
L'archive ouverte pluridisciplinaire HAL, est destinée au dépôt et à la diffusion de documents scientifiques de niveau recherche, publiés ou non, émanant des établissements d'enseignement et de recherche français ou étrangers, des laboratoires publics ou privés. 


\title{
Seasonal variation of pollution biomarkers to assess the impact on health status of juvenile Pacific oysters Crassostrea gigas exposed in situ
}

\author{
Andrea Luna-Acosta • Paco Bustamante • Joachim Godefroy • Ingrid Fruitier-Arnaudin • \\ Hélène Thomas-Guyon
}

\begin{abstract}
Background, aim, and scope In this study, a suite of sublethal stress biomarkers were analysed in juveniles of the sentinel species, the Pacific oyster Crassostrea gigas, with a view to using them as pollution monitoring tools. The aim of this work was (1) to study baseline seasonal variations of biomarkers in different body compartments of $C$. gigas in the reference site and, after selecting biomarkers presenting no seasonal variations, (2) to compare responses of these biomarkers between contaminated and reference sites.

Materials and methods Juvenile oysters were transplanted from Bouin (France), a reference site, to three different sites in Marennes-Oleron Bay (France), located in another water body and next to different contamination sources. Animals were exposed in situ for 3 months in summer, autumn and winter. The following biomarkers were measured: superoxide dismutase (SOD) and glutathione peroxidase (GPx) in gills and digestive gland, and lysozyme and phenoloxidase (PO) in plasma.

Results No significant seasonal variations for SOD in gills and digestive gland, GPx in gills, and PO in plasma were observed in the reference site. Significant differences in enzyme activity were observed between contaminated and reference sites for SOD in gills and digestive gland, and PO in plasma, depending on the body compartment, the season and/or the site.

Conclusions In conclusion, these data suggest the potential application of these biomarkers in C. gigas to provide ecologically relevant information and therefore, to be used as biomarkers in coastal pollution monitoring.
\end{abstract}

Keywords: Biomarkers • Pollution • Monitoring • Antioxidant enzymes • Immune defences • Crassostrea gigas

A. Luna-Acosta $(\bowtie) \bullet$ P. Bustamante $\bullet$ J. Godefroy $\bullet$ I. Fruitier-Arnaudin $\bullet$ H. Thomas-Guyon

Littoral, Environnement et Sociétés (LIENSs)

UMR 6250, Université de La Rochelle - CNRS

2, Rue Olympe de Gouges - 17000, La Rochelle, France

email : aluna1508@yahoo.com

tel : $+33(0) 546458791$

fax : $+33(0) 546507663$

\section{Background, aim and scope}

Sessile and filter-feeder organisms inhabiting coastal waters and estuaries, such as the Pacific oyster Crassostrea gigas (Thunberg 1753), are constantly in contact with various chemical products. Therefore, networks such as the National Monitoring Network (RNO) in France use this organism as a sentinel species to assess the presence of pollutants on coasts and estuaries. However, massive summer mortalities of this ecologically and economically important organism, and particularly of juvenile populations, have become a widespread concern in the world in recent decays (Cheney et al. 2000; Garnier et al. 2007; Perdue et al. 1981). Marennes-Oleron Bay is the first production site of this species in France (Soletchnik et al. 1999), but this area is also subjected to many recurring pollution by heavy metals, pesticides and polycyclic aromatic hydrocarbons (PAHs), brought mainly by the Charente River and to a less extent by the Seudre and the Gironde rivers (Miramand et al. 2003; Munaron 2004; Munaron et al. 2006). Nevertheless, environmental stress from pollutants seems to be an important determining factor signalled by the occurrence of, or by the increase of diseases (Lacoste et al. 2001).

To cope with this type of challenges, bivalve molluscs possess the two types of innate responses: cellular, i.e., phagocytosis and encapsulation, and humoral, i.e., lectines, cytokines, heat shock proteins, nitric oxide synthases, proteases, antimicrobial peptides, phenoloxidases (PO) and hydrolytic enzymes such as lysozymes (Tryphonas et al. 
2005). Moreover, during phagocytosis, reactive oxygen species (ROS), such as $\mathrm{O}_{2}{ }^{-}$and $\mathrm{H}_{2} \mathrm{O}_{2}$, play an important role in protection against pathogens. The content of ROS in the organism is regulated by antioxidant enzymes such as superoxide dismutase (SOD) and glutathione peroxidase (GPx) (Neumann et al. 2001). These antioxidant enzyme activities may be modulated by the presence of contaminants (Cavaletto et al. 2002; Cheung et al. 2004; Verlecar et al. 2007). Other immune parameters such as lysozyme and PO activities may also be modulated by contaminants. High concentrations of zinc ( $\mathrm{Zn})$ have shown to inhibit lysozyme activity in the sea star (Marthasterias glacialis) mucus (Stabili and Pagliara 2009). In addition to that, a 48-hours exposure of a soluble fraction of heavy fuel oil has shown to inhibit PO activity in plasma of C. gigas (Bado-Nilles et al. 2008), and the presence of trichlorfon has shown to inhibit PO activity in the giant freshwater prawn (Macrobrachium rosenbergii, Chang et al. 2006). Biomarkers are defined as measurements on body fluids, cells, tissues, or on whole animals that indicate the presence of contaminants in biochemical, cellular, physiological, behavioural or energetic terms (Bodin et al. 2004; Livingstone 2003 ; Magni et al. 2006; Ross et al. 2002). Therefore, these immune parameters may be used as effect biomarkers, i.e., to detect sensitive signals for deleterious effects of environmental contamination (Bernier et al. 1995; Luster et al. 1989). Some effect biomarkers, such as antioxidant enzymes, may also be used as exposure biomarkers, i.e., to detect if the organism has been exposed to pollutants (Winston and Di Giulio 1991). An increasing use of both types of biomarkers has appeared in recent years in programs such as the North Sea Task Force Monitoring Master Plan and the NOAA's National Status and Trends Program (Cajaraville et al. 2000).

Laboratory studies may help to identify biomarkers of interest. However, a lack of validation may occur when using these biomarkers in the field with organisms from contaminated and reference sites, e.g., immune parameters may vary depending on the season (Auffret and Oubella 1994; Oliver and Fisher 1995) and/or biomarker responses may vary depending on the body compartment of the organism that is analyzed (Amiard et al. 2006; Geffard et al. 2001). Therefore, it is important to know baseline seasonal variations of biomarkers, especially when they are used to monitor the presence and/or effect of contaminants during in situ studies. The aims of the present study were (1) to assess baseline seasonal variations of different biomarkers in different body compartments of C. gigas collected from a reference site and, after selecting biomarkers presenting no seasonal variations, (2) to compare responses of these biomarkers between contaminated and reference sites. To this end, juvenile Pacific oysters $C$. gigas were transplanted from Bouin (France), a reference site located far from pollution sources, to three different sites in Marennes-Oleron Bay, located in another water body and next to different contamination sources, for 3 months in summer, autumn and winter. Juveniles were chosen among other developmental stages since they have shown to be more sensitive to summer mortality events (Perdue et al 1981). Biomarker analyses were carried out by measuring SOD and GPx levels in gills and digestive gland and lysozyme and PO levels in plasma.

\section{Materials and methods}

\subsection{Study area and transplant design}

Juvenile Pacific oysters $C$. gigas (3-4 cm in height) were purchased from the oyster hatchery France Naissain, located at Bouin in Vendée, France ( $46^{\circ} 58^{\prime} 28^{\prime}$ ' North, $2^{\circ} 00^{\prime} 02^{\prime}$ ' West), considered as a reference site (Fig. 1 a; Geffard et al. 2002). All animals were issued from the same cohort in order to reduce genotype variability. Juveniles were transplanted from Bouin to three "contaminated" sites that were far from the reference site, in the Marennes-Oleron Bay, C1, C2 and C3, i.e., C1: Mus du Loup (45 46' 10" North, $1^{\circ} 08^{\prime}$ '30" West), mildly influenced by the Seudre River; C2: Boyard (45 58' 0" North, $1^{\circ} 15^{\prime} 0^{\prime \prime}$ West), mildly influenced by the Gironde and the Charente rivers; C3: Les Palles ( $45^{\circ} 58^{\prime} 0^{\prime \prime}$ North, $1^{\circ} 08^{\prime}$ 0"), highly influenced by the Charente River (Fig. 1b). Three months after transplantation, nine oysters from each site were collected and were processed immediately after their arrival in the laboratory. Experiments were carried out in summer, autumn and winter 2008.

\subsection{Sample procedure}

Pooled gills, digestive glands and plasma of three oysters were used for each replicate sample, and three replicates were prepared per season and per site. After opening the oyster shells by cutting off the adductor muscle, a quantity of haemolymph ( 0.3-0.5 $\mathrm{mL}$ for the three oysters) was withdrawn and centrifuged $\left(260 \mathrm{xg}, 10 \mathrm{~min}, 4^{\circ} \mathrm{C}\right)$ to separate the cellular fraction from the plasma. Gills and digestive gland were removed from oysters. For a pool of three oysters, about $0.7 \pm 0.1 \mathrm{~g}$ of gills and $4.2 \pm 1.2 \mathrm{~g}$ of digestive gland were homogenized at $4^{\circ} \mathrm{C}$ in $0.1 \mathrm{M}$ Tris $\mathrm{HCl}$ buffer $\mathrm{pH} 7.0$ $\left(0.45 \mathrm{M} \mathrm{NaCl}, 26 \mathrm{mM} \mathrm{MgCl} 2,10 \mathrm{mM} \mathrm{CaCl}_{2} ; 0.5 \mathrm{ml}\right.$ of buffer $\mathrm{g}^{-1}$ of fresh weight for the gills and $1 \mathrm{ml} \mathrm{g} \mathrm{g}^{-1}$ of fresh weight for the digestive gland), using an Ultra Turrax (T25 basic, IKA-WERKE) and a Thomas-Potter homogenizer 
(IKA-Labortechnik RW 20.n, size $0.13-0.18 \mathrm{~mm}, \mathrm{BB}$ ). The homogenate was centrifuged at $10,000 \mathrm{xg}$ for $10 \mathrm{~min}$ at $4^{\circ} \mathrm{C}$. The resulting supernatant was collected for enzymatic studies.

\subsection{Biochemical analysis}

Superoxide dismutase assay $\bullet$ SOD was determined by an indirect method (Therond et al. 1996), based on competition of SOD with iodonitrotetrazolium (INT) for dismutation of superoxide anion $\left(\mathrm{O}_{2}^{-}\right)$. In the presence of $\mathrm{O}_{2}^{-}$, INT is reduced into a red formazan dye that can be measured at $505 \mathrm{~nm}$ at $25^{\circ} \mathrm{C}$ (kit Ransod SD 125, Randox, France). One unit of SOD is defined as the amount of enzyme that promotes a 50\% decrease in the rate of INT reduction.

Glutathione peroxidase assay • GPx activity was determined according to the method of Paglia and Valentine (1967). In the presence of glutathione reductase and substrates (i.e., reduced glutathione and cumene hydroperoxide), the decrease of absorbance at $340 \mathrm{~nm}$ is proportional to the reduction of the oxidised glutathione by NADPH, H+ (Kit Ransel RS 504, Randox, France). One unit of GPx oxidises $1 \mu \mathrm{mol}$ of NADPH $\left(\varepsilon_{\mathrm{NADPH}}=6.22 \mathrm{mM}^{-1} \mathrm{~cm}^{-1}\right)$ per minute.

Lysozyme assay $\bullet$ Lysozyme assay was done in triplicate for each sample and compared against hen egg white lysozyme standards $\left(0.4-40 \mathrm{~g} \mathrm{ml}^{-1}\right)$, in the presence of Micrococcus lysodeikticus (Sigma-Aldrich, France). One unit of lysozyme corresponds to the amount of enzyme that diminishes absorbance at $450 \mathrm{~nm}$ of 0.001 per minute at $\mathrm{pH} 7.0$, at $25^{\circ} \mathrm{C}$ (Soudant et al. 2004).

Phenoloxidase assay • PO levels in plasma have been reported to be higher than PO levels in haemocytes of $C$. gigas (Hellio et al. 2007). Therefore, PO assay was measured in plasma and was carried out in triplicate for each sample in the presence of $100 \mathrm{mM}$ dopamine and $0.1 \mathrm{M}$ Tris $\mathrm{HCl}$ buffer, $\mathrm{pH} 7.0\left(0.45 \mathrm{M} \mathrm{NaCl}, 26 \mathrm{mM} \mathrm{MgCl}, 10 \mathrm{mM} \mathrm{CaCl}_{2}\right.$; Sigma-Aldrich, France). PO activity was followed by monitoring the increase of absorbance at $490 \mathrm{~nm}$ for $4 \mathrm{~h}$. Nonenzymatic oxidation by the substrate was followed in wells without plasma and subtracted to oxidation of the substrate with plasma. One unit of PO specific activity corresponds to the amount of enzyme that catalyzes the production of $1 \mu$ mole of dopachrome $\left(\varepsilon_{\text {Dopachrome }}=3,300 \mathrm{M}^{-1} \mathrm{~cm}^{-1}\right)$ per minute (Pomerantz 1963, Fenoll et al. 2002).

Protein assay - All activities were expressed in relation to protein concentration measured according to the Lowry method with slight modifications, by using bicinchoninic acid and copper sulphate 4\% (Smith et al. 1985). Serum albumin was used as standard (Sigma-Aldrich, France).

Statistical analysis $\bullet$ All results were expressed as mean \pm standard deviation (SD). Statistical analysis was carried out with SYSTAT 11.0 software. Differences among seasons were checked for the reference site. For the same season, biomarkers responses were compared between contaminated and reference sites. Data were tested for normal distribution (Shapiro test) and homogeneity of variances (Bartlett test). Student's $t$ test was performed to analyze results. Kruskal-Wallis nonparametric test, followed by Dunn's post hoc test, was performed when data were not normally distributed or when they exhibited heterogeneous variances (Zar, 1984). Statistical significance was defined as being at the level of $p<0.05$ or $p<0.01$.

\section{Results}

\subsection{Seasonal variations of biomarkers in the reference site}

The results of SOD and GPx levels in gills and in digestive gland measured in oysters collected from the reference site in summer, autumn, and winter are summarized in Fig. 2. There were no statistically relevant seasonal differences $(p>0.05)$ in SOD levels in gills (Fig. 2a) and in digestive gland (Fig. 2b). However, GPx baseline seasonal variations differed between gills and digestive gland: while no significant differences $(p>0.05)$ were observed in GPx levels in gills in summer, autumn and winter $\left(24.83 \pm 7.44,16.58 \pm 4.38\right.$ and $16.03 \pm 8.90 \mathrm{U} \mathrm{GPx} \mathrm{mg}^{-1} \mathrm{protein}$, respectively; Fig. $2 c)$, significant differences $(p<0.01)$ were observed in the digestive gland (Fig. 2d). Indeed, GPx levels in the digestive gland in summer were about twofold lower than GPx levels in autumn and winter $(38.29 \pm 8.68,64.55 \pm 11.15$ and 77.51 $\pm 5.37 \mathrm{U} \mathrm{GPx} \mathrm{mg}^{-1}$ protein, respectively; Fig. 2d).

Studies on lysozyme levels were carried out in plasma of $C$. gigas. Significant differences in plasmatic lysozyme levels $(p<0.01)$ were observed in oysters collected at the three different seasons (Fig. 3a). Lowest lysozyme levels were observed in winter, when compared to summer and autumn $(42.90 \pm 4.07,51.94 \pm 3.27$ and $64.44 \pm 3.93$ U lysozyme $\mathrm{mg}^{-1}$ protein, respectively). No statistically relevant seasonal differences $(p>0.05)$ were observed in plasmatic PO levels, i.e., in summer, autumn and winter (53.90 $\pm 9.77,51.81 \pm 9.32$ and $52.45 \pm 7.99 \mathrm{U} \mathrm{PO} \mathrm{mg}^{-1}$ protein, respectively; Fig. 3b). Therefore, since no significant seasonal differences were observed in SOD in gills and digestive gland, GPx in gills, and PO in plasma, these biomarkers were selected for further studies. 


\subsection{Biomarker responses in contaminated sites}

The results of SOD levels in gills and in digestive gland, GPx levels in gills and PO levels in plasma collected from the three contaminated sites, i.e., C1 (Mus du Loup), C2 (Boyard), and C3 (Les Palles) and from the reference site, R (Bouin), are summarized in Fig. 4. In the present comparison, responses of biomarkers in C3 were measured only in summer and winter.

There were statistically significant differences in SOD levels in gills for the three contaminated sites C1, C2 and C3 in summer (Fig. 4a). Indeed, SOD levels in gills were lower in contaminated sites as compared to the reference site. In autumn, no significant differences were observed. In winter, SOD contents in gills were lower only in C2 when compared to the reference site.

In the digestive gland, statistically significant differences in SOD levels were observed depending on the season and/or the site (Fig. 4b). Indeed, while higher SOD contents were observed in $\mathrm{C} 1$ and $\mathrm{C} 3$ in summer, no significant differences were observed in autumn for $\mathrm{C} 1$ and $\mathrm{C} 2$. In winter, higher contents of SOD were observed in $\mathrm{C} 1$ and $\mathrm{C} 2$, and lower contents were observed in $\mathrm{C} 3$.

The results of GPx levels in gills in contaminated and reference sites are summarized in Fig. 4c. No significant differences were observed in summer for $\mathrm{C} 1, \mathrm{C} 2, \mathrm{C} 3$, in autumn for $\mathrm{C} 1$, and in winter for C3. Low GPx levels were measured in autumn in $\mathrm{C} 2$ and winter in C3, and high GPx levels were measured in winter in C1.

Results on plasmatic PO levels revealed significantly lower levels in summer in C1, C2 and C3 and in autumn in C1 and $\mathrm{C} 2$, but higher levels in winter in $\mathrm{C} 1$ and $\mathrm{C} 2$, when compared to the reference site (Fig. 4d).

\section{Discussion}

Specific biomarkers are often used for studies in laboratory-controlled conditions (e.g., Boutet et al. 2002, Guilhermino et al. 1996). However, in the field, environmental conditions may modulate responses of biomarkers (Matsunaga et al. 1989; Monserrat et al. 2007; Neumann and Peter 1987; Sepcic et al. 1998). Moreover, compensatory adaptive mechanisms between different biomarkers may occur as well (Regoli and Principato 1995) and biomarker responses may differ depending on the body compartment of the organism that is analyzed (Amiard et al. 2006; Geffard et al. 2001). In the green-lipped mussel, Perna viridis, seasonal SOD variations observed in gills and digestive gland were likely to be due, in part, to variations of temperature in the water column (Verlecar et al. 2008). In the case of the present study, no seasonal variations were observed in SOD in gills and digestive gland in the reference site. This suggests that antioxidant modulations differ between species and that is necessary to study baseline levels on the organism of interest before comparing biomarker responses between contaminated and reference sites.

In the present study, significant seasonal differences were observed in GPx levels in digestive gland in the reference site, with lower levels observed in summer. These results were in agreement with other studies that revealed similar seasonal variations of GPx in P. viridis from Arabian Sea (Verlecar et al. 2008). Winter is a period where oxidative stress is known to be high in bivalves (Manduzio et al. 2004). Therefore, high GPx activities in the digestive gland in autumn and winter may be a consequence of high oxidative stress. It is important to notice that no seasonal variations were observed in GPx levels in gills, making studies on pollution monitoring more interesting in this body compartment. Moreover, these results are in agreement with Manduzio et al. (2004) who suggested that biomonitoring studies dealing with oxidative stress in the blue mussel, Mytilus edulis, should preferentially be carried out in the gills rather than in the digestive gland.

In the present study, significant seasonal differences were observed in plasmatic lysozyme activity. Results revealed lower levels in winter and summer. Low lysozyme levels in summer were in agreement with results in other molluscan and nonmolluscan species (Chu et al. 1995; Hutchinson and Manning 1996). However, in the present study, low levels were also observed in winter. Even if generally low lysozyme levels are associated to the reproductive cycle of oysters in summer, low levels have also been found in the flat oyster Ostrea edulis in winter (Cronin et al. 2001). This suggests that low lysozyme levels are not necessarily associated to the reproductive cycle of oysters, which starts at the end of spring (Fabioux et al. 2005). No significant seasonal differences were observed in PO levels in plasma. However, seasonal variations of PO activities have been reported in different species (Ferrer et al. 1989; Hauton et al. 1997; Travers et al. 2008). These seasonal variations have been attributed to bacterial population contents in the water column or to the reproductive state of the organism. Ferrer et al. (1989) observed seasonal variations in PO activity after treating with trypsin but not in endogenously active PO in the spiny lobster Panulirus argus. Therefore, results of the present study are in agreement with Ferrer et al. (1989) since, in the present study, only endogenously active PO levels were measured. No significant seasonal variations were observed in SOD in gills and digestive gland, GPx in gills, and $\mathrm{PO}$ in plasma in the reference site. Interestingly, these results suggest that differences in water temperature $(18.39 \pm 1.73$ in summer, $15.33 \pm 2.89$ in autumn and $8.83 \pm 2.18$ in winter,;Table 1), in age (12 months in summer, 15 months in autumn, 18 months in winter) and in condition index (31.85 \pm 5.43 in summer, $23.90 \pm 1.42$ in autumn and $17.15 \pm 1.42$ in 
winter; Table 1) between seasons do not modulate responses of these biomarkers. Consequently, SOD in gills and digestive gland, GPx in gills, and PO in plasma were measured in oysters transplanted to different contaminated sites in Marennes-Oleron Bay.

Comparisons of biomarker responses between reference and contaminated sites revealed that (1) SOD levels in gills were generally lower, (2) SOD levels in digestive gland were generally higher, (3) GPx levels in gills were not modulated in summer but were lower in autumn in one contaminated site and lower or higher in summer depending on the contaminated site, and (4) PO levels were generally lower in summer and autumn and higher in winter. Differences in pollutant contents between contaminated and reference sites could explain differences observed in biomarker responses, e.g., in the case of GPx in gills or SOD in the digestive gland, as it has been shown by other studies carried out in different contaminated sites (Bodin et al. 2004; Valdez Domingos et al. 2007). Marennes-Oleron Bay is an area subjected to many recurring pollution, brought mainly by the Charente River (i.e., contaminated site C3) and to a less extent by the Gironde (i.e., C2) and the Seudre rivers (i.e., C1). The recrudescence use of herbicides in agriculture implies the transfer towards the aquatic environment of new pollutants in estuarine areas (Munaron 2004; Munaron et al. 2006). In 2001, the Charente river discharged approximately $1,360 \mathrm{~kg}$ of herbicides and, in 2002 , about $510 \mathrm{~kg}$ (Munaron 2004). For most herbicides that were studied, summer (July, August and September) corresponded to the period when quantities of herbicides provided by the Charente river were the lowest, i.e., between 12 and $30 \mathrm{~kg}$ of herbicides per month and the peak concentrations occurred especially at times when treatments were applied within the watershed, e.g., in May 2001, $400 \mathrm{~kg}$ of herbicides were carried down to the estuary in 1 month. Peak concentrations from 0.1 to $1 \mu \mathrm{g} \mathrm{L}^{-1}$ have been reported for herbicides such as atrazine, isoproturon, diuron, and glyphosate in the Marennes-Oleron Bay (Burgeot et al. 2007). Moreover, industrial releases bring many heavy metals in these same estuarine areas (Miramand et al. 2003). Indeed, increasing levels of heavy metals [silver (Ag), cadmium (Cd), chromium $(\mathrm{Cr})$, copper $(\mathrm{Cu})$, nickel $(\mathrm{Ni})$, vanadium $(\mathrm{V})$, and zinc $(\mathrm{Zn})]$, have been reported in Marennes-Oleron Bay (Miramand et al. 2003). Similarly, these authors reported high PAHs contents in sediments and organisms from the Marennes-Oleron Bay. Some pollutant contents have been reported in sites chosen for the present study: high $\mathrm{Cd}, \mathrm{Hg}$, dichlorodiphenyltricholoroethane (DDT) and metabolites, lindane and fluoranthene contents have been detected in C1, high $\mathrm{Cd}, \mathrm{Hg}$ and lindane contents have been detected in $\mathrm{C} 2$, and high $\mathrm{Ag}, \mathrm{Cd}, \mathrm{Hg}, \mathrm{Zn}$, contents have been detected in C3 (Table 1). These pollutants are, therefore, likely to strongly influence the biomarkers levels in oyster tissues and fluids.

Among all biomarkers assessed in the reference site, only SOD levels in gills and digestive gland, GPx levels in gills and PO levels in plasma displayed low variations between seasons. Interestingly, some of these biomarkers were modulated depending on the season and this, for the three contaminated sites. Therefore, modulations on biomarker responses could be due to (1) abiotic or biotic factors in this area such as temperature, salinity, $\mathrm{pH}$ or food supply (Khessiba et al. 2005; Kirchin et al. 1992; Lima et al. 2007; Prevodnik et al. 2007; Verlecar et al. 2007), (2) modulations of contaminant contents through seasons (Niyogi et al. 2001), and/or (3) an additive effect of temperature variations and contaminant contents in these areas. Indeed, Ringwood et al. (2002) reported a correlation between lysosomal destabilization in deployed oysters Crassostrea virginica and tissue metal concentrations. The authors suggested that adverse effects observed in winter could be due to seasonal differences in physico-chemical factors, such as reduced levels of acid volatile sulfides, which could increase the bioavailability of metals during winter. In the present study, differences in condition index were observed depending on the season and the site. Even if differences observed in the reference site suggest that this parameter do not induce modulations of the biomarkers that were selected for the present study, differences of condition index were observed between the reference and the contaminated sites. Indeed, when comparing condition index between reference and contaminated sites, this parameter was higher in summer in the three contaminated sites, higher or lower in autumn depending on the site, and higher in winter in one contaminated site (Table 1). These differences may be due to differences in food supply or environmental stressors such as changes in temperature. However, temperature data do not reveal differences between sites and chlorophyll $a$ content in the water column is not always correlated with condition index of oysters (Table 1). Hence, differences in condition index may be due to differences in food composition between sites. However, while results suggest a negative correlation between condition index and GPx levels in gills and PO levels in plasma, no correlation is observed in autumn and winter. Moreover, the presence of pollutants may also induce differences in condition index. Lannig et al. (2006) reported no significant change in condition, survival rate, and lipid peroxidation in oysters, $C$. virginica, exposed to elevated temperature. However, in oysters exposed to both temperature and $\mathrm{Cd}$ stresses, high mortality, low condition index, and elevated lipid peroxidation were observed, implying a synergism between elevated temperatures and Cd stress on their energy metabolism. In the Marennes-Oleron area, the period when herbicides are sprayed on the crops, combined to rainfall events, coincides with the oyster-breeding season, and these events have been suggested to influence summer oyster mortalities (Munaron 2004; Munaron et al. 2006). Therefore, more special attention should be carried out between condition index, food composition, pollutant contents, and response of biomarkers.

In conclusion, response biomarkers were modulated depending on (1) the oyster body compartment, (2) the season, and (3) the site. Therefore, results of this work suggest that SOD in gills and digestive gland, GPx in gills, and PO levels in 
plasma could be biomarkers of interest to assess the impact of pollutants on health status in juveniles of $C$. gigas. Further similar studies should be done on these biomarkers in other contaminated sites (e.g., Valdez Domingos et al. 2007). Moreover, similar studies should be carried out with other biomarkers in this sentinel species in order to establish baseline levels of different biomarkers of interest for coastal pollution monitoring studies.

Acknowledgments This study was supported by a Ph.D. grant from the Conseil Général de la Charente-Maritime. The Région PoitouCharentes, the Région Aquitaine, the Conseil Général de la Charente-Maritime, the Conseil Général de la Gironde, the Agence de l’Eau Adour-Garonne are acknowledged for financial support for the project "Défi Cadmium". The authors wish to thank M. Baudrimont and D. Fichet for supporting this study through the "Défi Cadmium" project. The authors also acknowledge C. Trichet and D. Vilday for their assistance during the study and the Ifremer networks RNO and Razlec, the "Site Ifremer consacré à l'environnement littoral", and especially O. Le Moine, P. Soletchnik, S. Guesdon, P-G. Sauriau, P. Miramand, and T. Guyot for data and references from Marennes-Oleron Bay. The authors thank F. Healy (Centre Inter-Pôles d'Enseignement des Langues, Université La Rochelle) for critical reading of this document.

\section{References}

Amiard J, Amiard-Triquet C, Barka S, Pellerin J, Rainbow P (2006) Metallothioneins in aquatic invertebrates: Their role in metal detoxification and their use as biomarkers. Aquat Tox 76:160-202

Auffret M, Oubella R (1994) Cytometric parameters of bivalve molluscs: effect of environmental factors. In: Stolen J, Fletcher T (eds) Modulators of fish immune responses, Vol 1. SOS Publications, Fair Haven, CT, pp 23-32

Bado-Nilles A, Gagnaire B, Thomas-Guyon H, Le Floch S, Renault T (2008) Effects of 16 pure hydrocarbons and two oils on haemocyte and haemolymphatic parameters in the Pacific oyster, Crassostrea gigas (Thunberg). Toxicol In Vitro 22:1610-1617

Bernier J, Brousseau P, Krzystyniak K, Tryphonas H, Fournier M (1995) Immunotoxicity of heavy metals in relation to Great Lakes. Env Health Pers 103:23-24

Bodin N, Burgeot T, Stanisiere J, Bocquene G, Menard D, Minier C, Boutet I, Amat A, Cherel Y, Budzinski H (2004) Seasonal variations of a battery of biomarkers and physiological indices for the mussel Mytilus galloprovincialis transplanted into the northwest Mediterranean Sea. Comp Biochem Physiol 138C:411-427

Boutet I, Tanguy A, Auffret M, Riso R, Moraga D (2002) Immunochemical quantification of metallothioneins in marine molluscs: Characterization of a metal exposure bioindicator. Environ Toxicol Chem 21:1009-1014

Burgeot T, Gagnaire B, Renault T, Haure J, Moraga D, David E, Boutet I, Sauriau PG, Malet N, Bouchet V, Le Roux A, Lapègue S, Bouilly K, Le Moullac G, Arzul G, Knoery J, Quiniou F, Bacher C, Soletchnik P (2007) Summer mortality of Pacific oyster Crassostrea gigas. In: Samain JF, McCombie H (ed) The Morest Project, Ifremer/Quæ, Versailles, France, pp 107-151

Cajaraville M, Bebianno M, Blasco J, Porte C, Sarasquete C, Viarengo A (2000) The use of biomarkers to assess the impact of pollution in coastal environments of the Iberian Peninsula: A practical approach. Sci Total Environ 247:295-311

Cavaletto M, Ghezzi A, Burlando B, Evangelisti V, Ceratto N, Viarengo A (2002) Effect of hydrogen peroxide on antioxidant enzymes and metallothionein level in the digestive gland of Mytilus galloprovincialis. Comp Biochem Physiol 131C:447-455

Chang C, Lee P, Liu C, Cheng W (2006) Trichlorfon, an organophosphorus insecticide, depresses the immune responses and resistance to Lactococcus garvieae of the giant freshwater prawn Macrobrachium rosenbergii. Fish Shellfish Immun 20:574-585

Cheney D, Macdonald B, Elston R (2000) Summer mortality of Pacific oysters Crassostrea gigas (Thunberg): Initial findings on multiple environmental stressors in Puget Sound, Washington, 1998. J Shellfish Res 19:353-359

Cheung C, Siu W, Richardson B, De Luca-Abbott S, Lam P (2004) Antioxidant responses to benzo[a]pyrene and Aroclor 1254 exposure in the green-lipped mussel, Perna viridis. Env Poll 128:393-403

Chu F, Volety A, La Peyre J (1995) Annual variation of hemolymph components and Perkinsus marinus infection in oysters sampled from Deep Water Shoal, James River, Virginia. J Shellfish Res 14:263

Cronin M, Culoty S, Mulcahy M (2001) Lysozyme activity and protein concentration in the haemolymph of the flat oyster Ostrea edulis (L.). Fish Shellfish Immun 11:611-622

Fabioux C, Huvet A, Le Souchu P, Le Pennec M, Pouvreau S (2005) Temperature and photoperiod drive Crassostrea gigas reproductive internal clock. Aquaculture 250: 458-470

Fenoll LG, Rodriguez-Lopez JN, Garcia-Molina F, Garcia-Canovas F, Tudela J (2002) Unification for the expression of the monophenolase and diphenolase activities of tyrosinase. IUBMB Life 54:137-41

Ferrer O, Koburger E, Simpson B, Gleeson R, Marshall M (1989) Phenoloxidase levels in Florida spiny lobster (Panulirus argus): relationship to season and molting stage. Comp Biochem Physiol 93B:595-599

Garnier M, Labreuche I, Garcia C, Robert M, Nicolas J (2007) Evidence for the involvement of pathogenic bacteria in summer mortalities of the Pacific oyster Crassostrea gigas. Microb Ecol 53:187-196

Geffard A, Amiard-Triquet C, Amiard J, Mouneyrac C (2001) Temporal variations of metallothionein and metal concentrations in the digestive gland of oysters (Crassostrea gigas) from a clean and a metal-rich site. Biomarkers 6:91-107

Geffard A, Amiard J, Amiard-Triquet C (2002) Kinetics of metal elimination in oysters from a contaminated estuary. Comp Biochem Physiol 131C:281-293

Guilhermino L, Lopes M, Carvalho A, Soares M (1996) Inhibition of acetylcholinesterase activity as effect criterion in acute tests with Daphnia Magna. Chemosphere 32:727-738

Hauton C, Hawkins L, Williams J (1997) In situ variability in phenoloxidase activity in the shore crab, Carcinus maenas (L.). Comp Biochem Physiol 117B:267-271

Hellio C, Bado-Nilles A, Gagnaire B, Renault T, Thomas-Guyon H (2007) Demonstration of a true phenoloxidase activity and activation of a ProPO cascade in Pacific oyster, Crassostrea gigas (Thunberg) in vitro. Fish Shellfish Immun 22:433-440

Hutchinson T, Manning M (1996) Seasonal trends in serum lysozyme activity and total protein concentration in dab (Limanda limanda L.) sampled from Lyme Bay, UK. Fish Shellfish Immun 6:473-482 
Khessiba A, Romeo M, Aïssa P (2005) Effects of some environmental parameters on catalase activity measured in the mussel (Mytilus galloprovincialis) exposed to lindane. Env Poll 133:275-281

Kirchin M, Wiseman A, Livingstone D (1992) Seasonal and sex variation in the mixed-function oxygenase system of digestive gland microsomes of the comon mussel, Mytilus edulis L. Comp Biochem Physiol 101C:81-91

Lacoste A, Jalabert F, Malham S, Cueff A, Poulet S (2001) Stress and stress-induced neuroendocrine changes increase the susceptibility of juvenile oysters (Crassostrea gigas) to Vibrio splendidus. App Env Micro 67:2304-2309

Lannig G, Flores J, Sokolova I (2006) Temperature-dependent stress response in oysters, Crassostrea virginica: Pollution reduced temperature tolerance in oysters. Aquat Tox 79:278-287

Lima I, Moreira S, Osten J, Soares A, Guilhermino L (2007) Biochemical responses of the marine mussel Mytilus galloprovincialis to petrochemical environmental contamination along the North-western coast of Portugal. Chemosphere 66:1230-1242

Livingstone D (2003) Biotechnology and pollution monitoring: Use of molecular biomarkers in the aquatic environment. J Chem Tech Biotech 57:195-211

Lobel P, Wright D (1982) Relationship between body zinc concentration and allometric growth measurements in the mussel Mytilus edulis. Mar Biol 66:145-150

Luster M, Ackermann M, Germolec D, Rosenthal G (1989) Perturbations of the immune system by xenobiotics. Env Health Pers 81:157-162

Magni P, De Falco G, Falugi C, Franzoni M, Monteverde M, Perrone E, Sgro M, Bolognesi C (2006) Genotoxicity biomarkers and acetylcholinesterase activity in natural populations of Mytilus galloprovincialis along a pollution gradient in the Gulf of Oristano (Sardinia, wester Mediterranean). Env Poll 142:65-72

Manduzio H, Monsinjon T, Galap C, Leboulenger F, Rocher B (2004) Seasonal variations in antioxidant defences in blue mussels Mytilus edulis collected from a polluted area: Major contributions in gills of an inducible isoform of $\mathrm{Cu} / \mathrm{Zn}$-superoxide dismutase and of glutathione S-transferase. Aquat Tox 70:83-93

Matsunaga S, Moore R, Niemczura W, Carmichael W (1989) Anatoxin-a(s), a potent anticholinesterase from Anabaena flos-aquae. J Am Chem Soc 111:8021-8023

Miramand P, Guyot T, Pigeot J (2003) Sources et impacts potentiels des micropolluants chimiques sur un écosystème littoral exploité: L'exemple des côtes de Charente-Maritime. J Phy IV (Proceedings) 108:3-6

Monserrat J, Martinez P, Geracitano L, Amado L, Martins C, Pinho G, Chaves I, Cravo M, Lima J, Bianchini A (2007) Pollution biomarkers in estuarine animals: Critical review and new perspectives. Comp Biochem Physiol 146C:221-234

Munaron D (2004) Etude des apports en herbicides et nutriments par la Charente: Modelisation de la dispersion de l'atrazine dans le bassin de Marennes-Oleron. PhD Thesis. Universite Pierre et Marie Curie Paris VI

Munaron D, Dubernet J, Delmas F, Stanisiere J, Scribe, P (2006) Assessment of the quantities of herbicides and nutrients brought down by the river Charente to the coast and modelling of the dispersion of atrazine in the Marennes-Oleron bay. Cah Biol Mar 47:85-92

Neumann N, Stafford J, Barreda D, Ainsworth A, Belosevic M (2001) Antimicrobial mechanisms of fish phagocytes and their role in host defense. Dev Comp Immunol 77:339-347

Neumann R, Peter H (1987) Insecticidal organophosphates: Nature made them first. Cell Mol Life Sci 43:1235-1237

Niyogi S, Biswas S, Sarker S, Datta G (2001) Antioxidant enzymes in brackishwater oyster, Saccostrea cucullata as potential biomarkers of polyaromatic hydrocarbon pollution in Hooghly Estuary seasonality and its consequences. Sci Total Environ 281:237-246

Oliver L, Fisher W (1995) Comparative form and function of oyster Crassostrea virginica hemocytes from Chesapeake Bay (Virginia) and Apalachicola Bay (Florida). Dis Aquat Org 22:217-225

Paglia D, Valentine W (1967) Studies on the quantitative and qualitative characterization of erythrocyte gluathione peroxidase. J Lab Clin Med 70:158-169

Perdue J, Beattie J, Chew K (1981) Some relationships between gametogenic cycle and summer mortality phenomenon in the Pacific oyster Crassostrea gigas in the Washington State. J Shellfish Res 1:9-16

Pomerantz S (1963) Separation, purification, and properties of two tyrosinases from hamster melanoma. J Biol Chem 238:2351-2357

Prevodnik A, Gardeström J, Lilja K, Elfwing T, McDonagh B, Petrovic N, Tedengren M, Sheehan D, Bollner T (2007) Oxidative stress in response to xenobiotics in the blue mussel Mytilus edulis L.: Evidence for variation along a natural salinity gradient of the Baltic Sea. Aquat Tox 82:63-71

Regoli F, Principato G (1995) Glutathione, glutathione-dependent and antioxidant enzymes in mussel, Mytilus galloprovincialis, exposed to metals under field and laboratory conditions: Implications for the use of biochemical biomarkers. Aquat Tox 31:143-164

Ringwood A, Hoguet J, Keppler C (2002) Seasonal variation in lysosomal destabilization in oysters, Crassostrea virginica. Mar Env Res 54:793-797

Ross K, Cooper N, Bidwell J, Elder J (2002) Genetic diversity and metal tolerance of two marine species: A comparison between populations from contaminated and reference sites. Mar Poll Bull 44:671-679

Sepcic K, Marcel V, Klaebe A, Turk T, Suput D, Fournier D (1998) Inhibition of acetylcholinesterase by an alkylpyridinium polymer from the marine sponge, Reniera sarai. Biochim Biophys Acta 1387:217-225

Smith P, Khron R, Hermanson G, Mallia A, Gartner F, Provanzano M, Fujimoto E, Goeke N, Olson B, Klenk D (1985) Measurement of protein using bicinchoninic acid. Anal Biochem 150:76-85

Soletchnik, P, Le Moine, O, Faury, N, Razet, D, Geairon, P, Goulletquer, P (1999) Mortalité de l'huître Crassostrea gigas dans le bassin de Marennes-Oléron: Etude de la variabilité spatiale de son environnement et de sa biologie par un système d'informations géographiques (SIG). Aquat Living Resour $12: 131-143$

Soudant P, Paillard C, Choquet G, Lambert C, Reid H, Marhic A, Donaghy L, Birbeck T (2004) Impact of season and rearing site on the physiological and immunological parameters of the Manila clam Venerupis (=Tapes, =Ruditapes) philippinarum. Aquaculture 229:401418

Stabili L, Pagliara P (2009) Effect of zinc on lysozyme-like activity of the seastar Marthasterias glacialis (Echinodermata, Astreroidea) mucus. J Invert Path 100:189-192

Therond P, Gerbaud P, Dimon S, Anderson W, Evain-Brion, Raynaud F (1996) Antioxidant enzymes in psoriatic fibroblasts and erythrocytes. J Invest Derm 106:1325-1331

Travers M, Le Goïc N, Huchette S, Koken M, Paillard C (2008) Summer immune depression associated with increased susceptibility of the European abalone, Haliotis tuberculata to Vibrio harveyi infection. Fish Shellfish Immun 25:800-808 
Tryphonas H, Fournier M, Blakley B, Smits J, Brousseau P (2005) Investigative Immunotoxicology. Informa HealthCare, London

Valdez Domingos F, Azevedo M, Silva M, Randi M, Freire C, Silva de Assis H, Oliveira Ribeiro C (2007) Multibiomarker assessment of three Brazilian estuaries using oysters as bioindicators. Env Res 105:350-363

Verlecar X, Jena K, Chainy G (2007) Biochemical markers of oxidative stress in Perna viridis exposed to mercury and temperature. Chemico-Biol Interactions 167:219-226

Verlecar X, Jena K, Chainy G (2008) Seasonal variation of oxidative biomarkers in gills and digestive gland of green-lipped mussel Perna viridis from Arabian Sea. Estuarine Coastal Shelf Sci 76:745-752

Winston G, Di Giulio R (1991) Prooxidant and antioxidant mechanisms in aquatic organisms. Aquat Tox 19:137-161

Zar J (1984) Biostatistical analysis. Prentice-Hall, New Jersey

Fig. 1 Estuarine sampling areas in French Atlantic coast: a localization of reference $(R)$ and contaminated $(C)$ sites in France and b localization of contaminated sites Mus du Loup (C1), Boyard (C2), and Les Palles (C3) in Marennes-Oleron Bay 


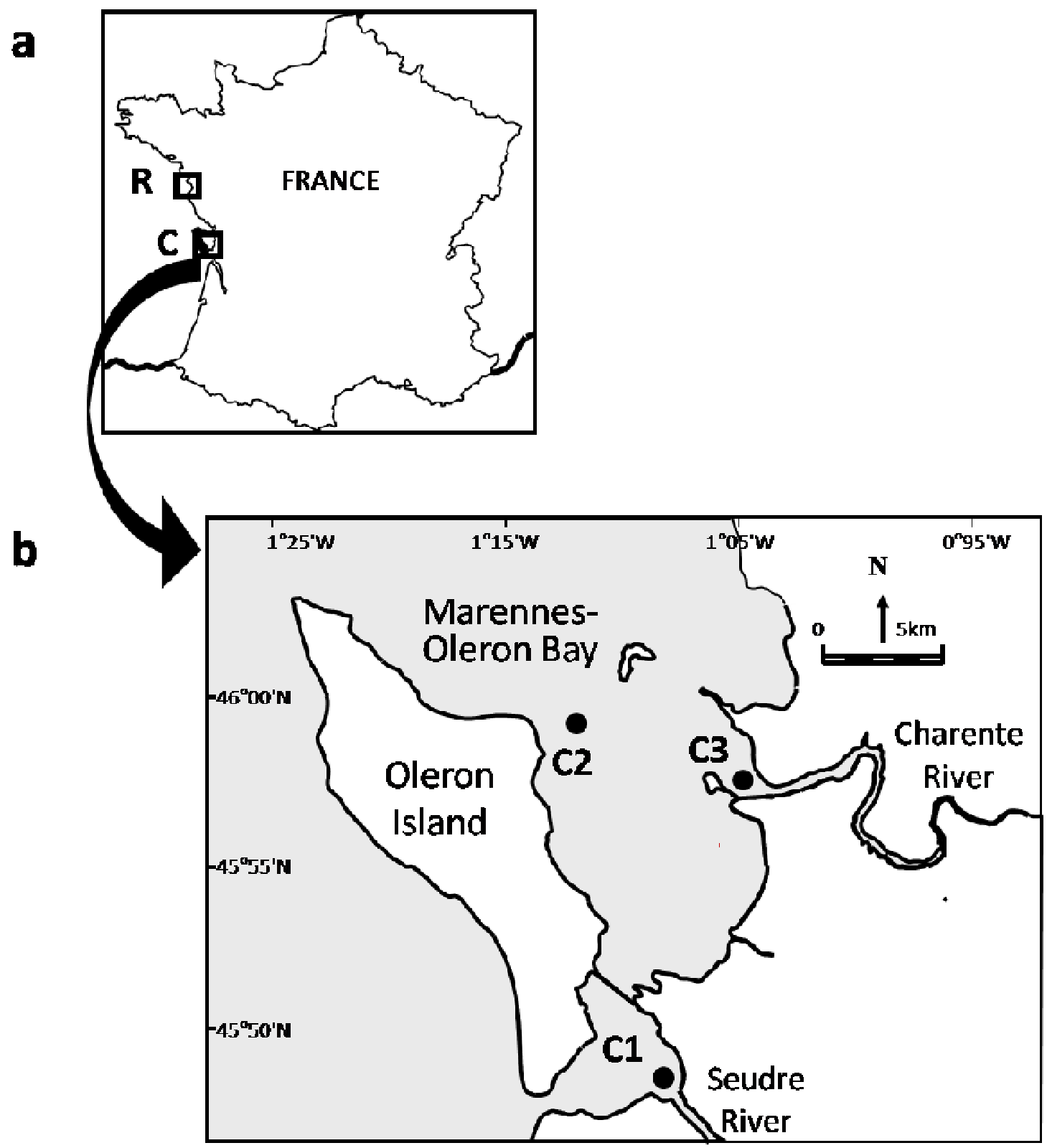

Fig. 2 Seasonal variations on SOD (a and $\mathbf{b}$; in units of SOD per minute per milligram of protein) and GPx (c and $\mathbf{d}$; in units of GPx per minute per milligram of protein) in gills and digestive gland of $C$. gigas collected from the reference site (Bouin). Letters indicate significant differences between seasons $(p<0.01)$. Data are expressed as mean \pm SD 


\section{Gills}

a

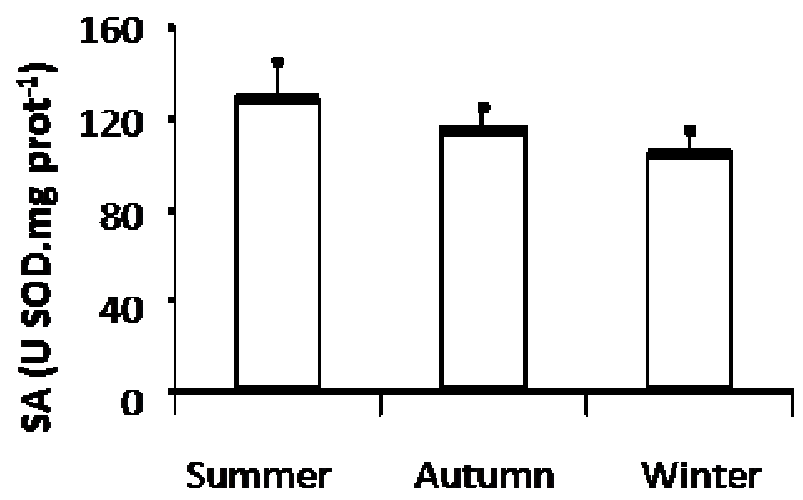

Gills

C

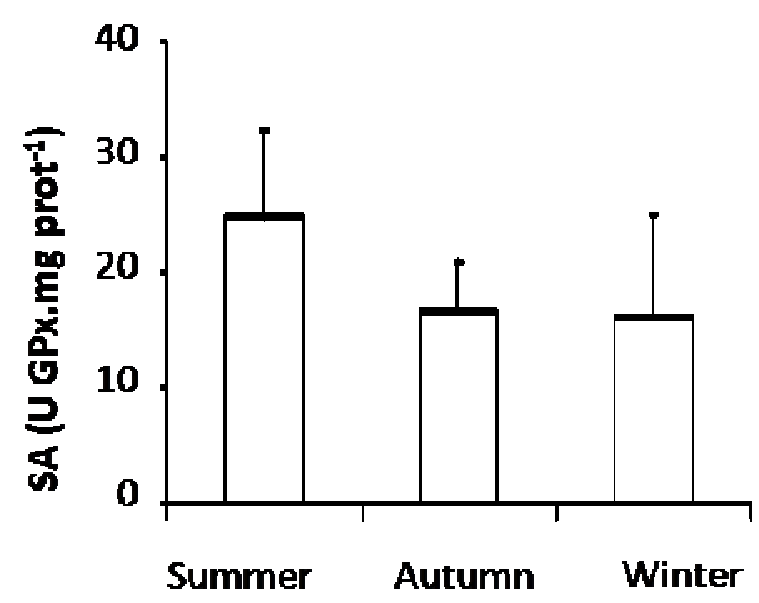

Digestive gland

b

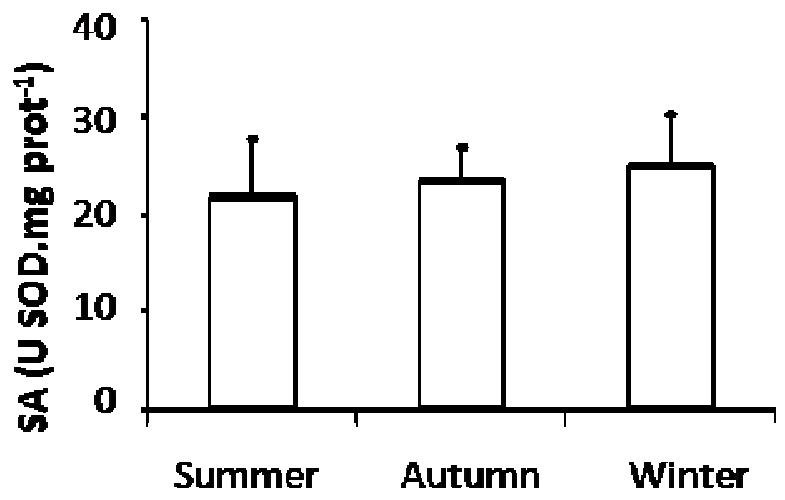

Digestive gland

d

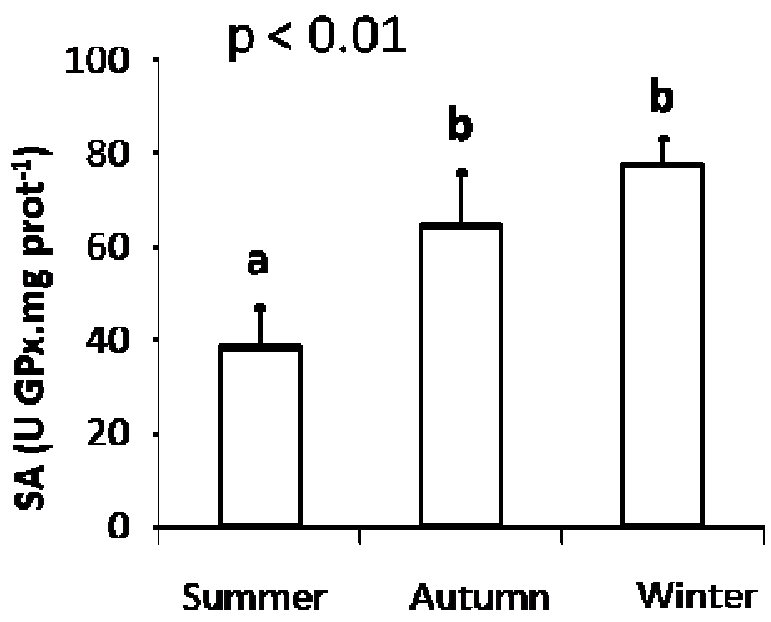


a

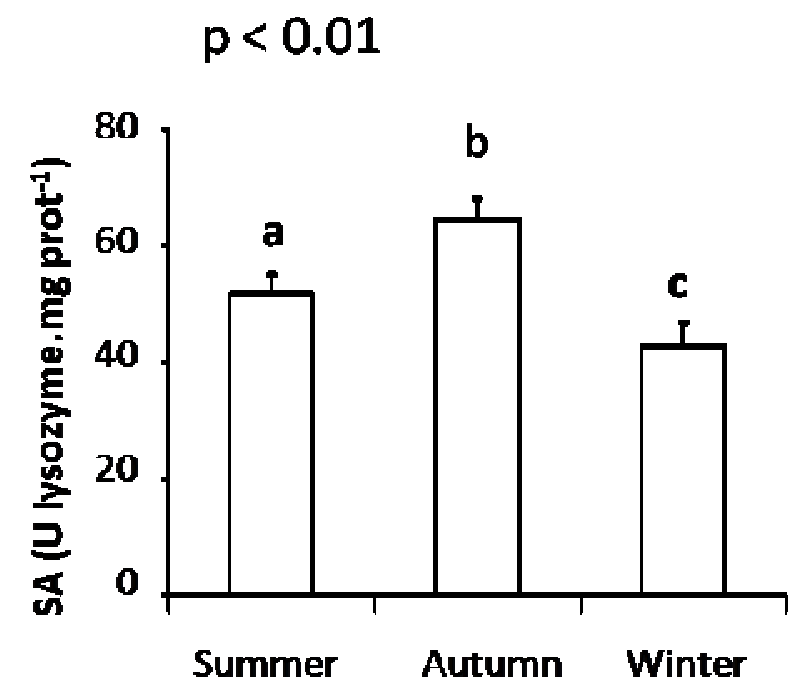

b

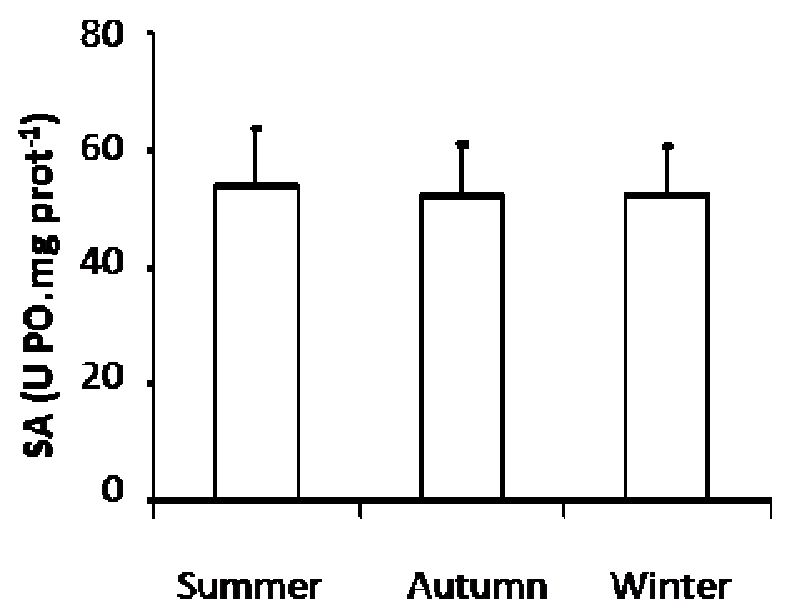


Fig. 4 SOD in gills and digestive gland, GPx in gills, and PO in plasma in C. gigas collected from contaminated and reference sites. $R$ reference site (Bouin, white bars), $C 1$ contaminated site 1 (Mus du Loup, light grey bars), $C 2$ contaminated site 2 (Boyard, dark grey bars), $C 3$ contaminated site 3 (Les Palles, black bars). Data are expressed as mean \pm SD. ${ }^{*} p<0.05 ; * * p<0.01$

a

Gills

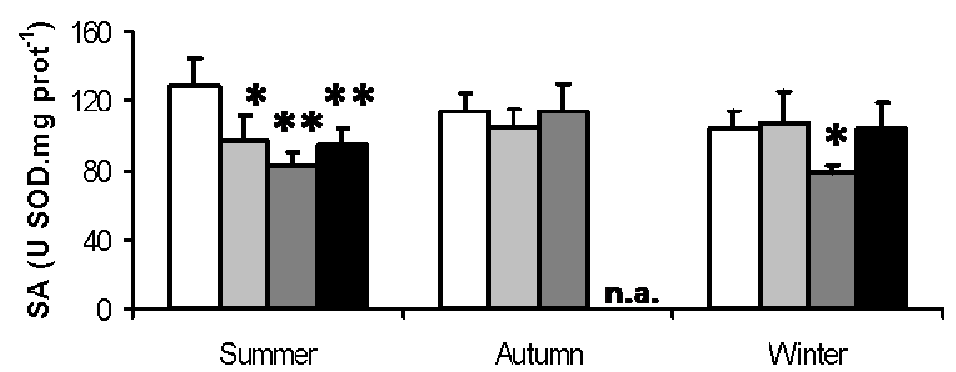

b
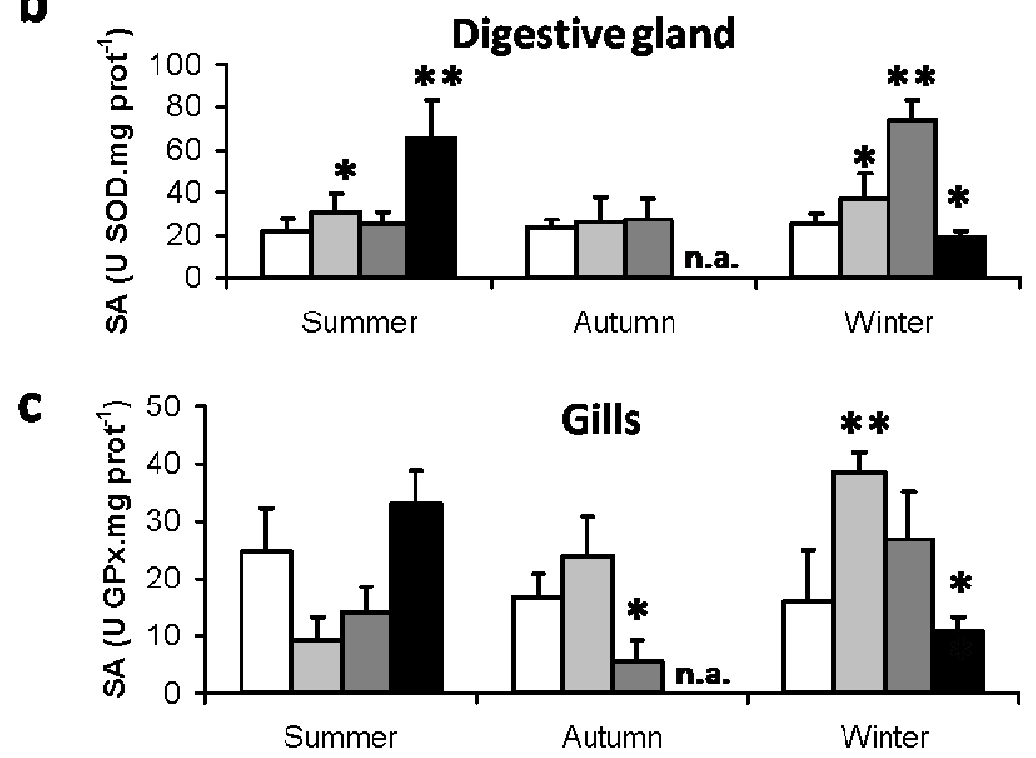

d
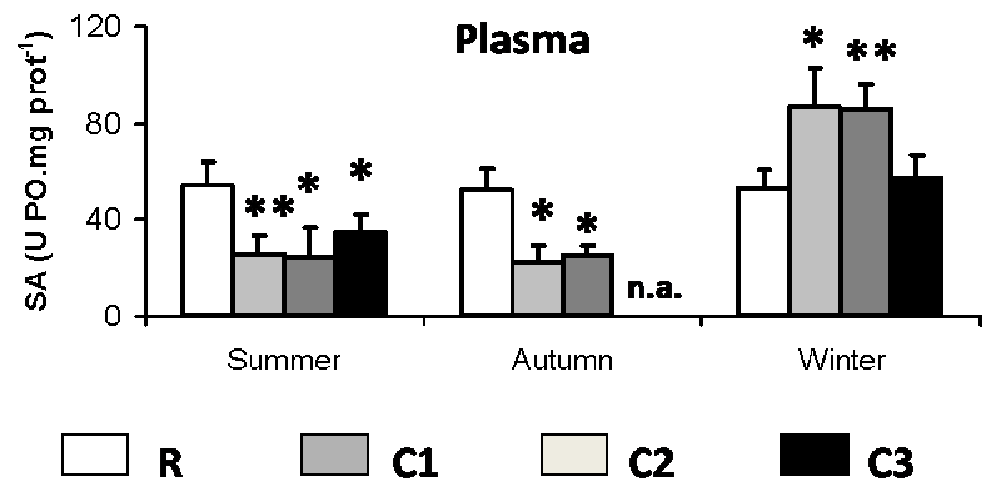
Table 1 Pollutant contents in oysters and physicochemical and biological parameters of the reference (Bouin, R) and contaminated sites (Mus du Loup, C1; Boyard, C2; Les Palles, C3) in summer (S), autumn (A), and winter (W) 2008

\begin{tabular}{|c|c|c|c|c|c|c|c|c|c|c|c|c|c|}
\hline & \multirow{2}{*}{$\begin{array}{c}\text { National } \\
\text { median }\end{array}$} & \multicolumn{3}{|l|}{$\mathrm{R}$} & \multicolumn{3}{|l|}{$\mathrm{C} 1$} & \multicolumn{3}{|l|}{$\mathrm{C} 2$} & \multicolumn{3}{|l|}{$\mathrm{C} 3$} \\
\hline & & $\mathrm{S}$ & A & $\mathrm{W}$ & $\mathrm{S}$ & A & W & $\mathrm{S}$ & A & $\mathrm{W}$ & $\mathrm{S}$ & A & W \\
\hline \multicolumn{14}{|l|}{$\begin{array}{l}\text { Pollutant contents }{ }^{\mathrm{a}} \\
\text { Metals }\left(\mathrm{mg} \cdot \mathrm{kg}^{-1}\right)\end{array}$} \\
\hline $\mathrm{Ag}$ & 7.69 & 19.50 & & & 12.30 & & & 16.20 & & & 29.90 & & \\
\hline $\mathrm{Cd}$ & 1.61 & 1.75 & & & 3.73 & & & 2.75 & & & 3.82 & & \\
\hline $\mathrm{Cr}$ & 0.84 & 1.07 & & & 1.23 & & & 1.04 & & & 1.29 & & \\
\hline $\mathrm{Cu}$ & 206 & 385 & & & 262 & & & 281 & & & 500 & & \\
\hline $\mathrm{Hg}$ & 0.20 & 0.19 & & & 0.32 & & & 0.32 & & & 0.36 & & \\
\hline $\mathrm{Ni}$ & 1.01 & 1.30 & & & 1.28 & & & 1.22 & & & 1.22 & & \\
\hline $\mathrm{Pb}$ & 1.30 & 1.30 & & & 1.60 & & & 1.45 & & & 1.55 & & \\
\hline $\mathrm{V}$ & 1.32 & 1.32 & & & 1.75 & & & 1.33 & & & 1.72 & & \\
\hline $\mathrm{Zn}$ & 2265 & 2360 & & & 2435 & & & 2680 & & & 4020 & & \\
\hline Pesticides $\left(\mu \mathrm{g} \cdot \mathrm{kg}^{-1}\right)$ & & & & & & & & & & & & & \\
\hline DDT, metabolites & 5.22 & 5.76 & & & 8.31 & & & 4.28 & & & 5.03 & & \\
\hline Lindane & 0.74 & 0.39 & & & 0.90 & & & 0.79 & & & 0.46 & & \\
\hline $\begin{array}{l}\text { PAHs }\left(\mu \mathrm{g} . \mathrm{kg}^{-1}\right) \\
\text { Fluoranthene }\end{array}$ & 27.0 & 20.2 & & & 33.7 & & & 27.8 & & & 23.5 & & \\
\hline Physicochemical parameters & & & & & & & & & & & & & \\
\hline Temperature $\left({ }^{\circ} \mathrm{C}\right)^{\mathrm{b}}$ & n.a. & $\begin{array}{l}18.39 \pm \\
1.73\end{array}$ & $\begin{array}{l}15.33 \pm \\
2.89\end{array}$ & $\begin{array}{l}8.83 \pm \\
2.18\end{array}$ & $\begin{array}{l}19.93 \pm \\
2.09\end{array}$ & $\begin{array}{l}15.59 \pm \\
3.12\end{array}$ & $\begin{array}{l}9.76 \pm \\
2.64\end{array}$ & $\begin{array}{l}19.26 \pm \\
1.96\end{array}$ & $\begin{array}{l}15.58 \pm \\
3.48\end{array}$ & $\begin{array}{l}9.36 \pm \\
1.97\end{array}$ & $\begin{array}{l}20.13 \pm \\
1.98\end{array}$ & $\begin{array}{l}16.35 \pm \\
3.49\end{array}$ & $\begin{array}{l}8.01 \pm \\
1.56\end{array}$ \\
\hline Temperature $\left({ }^{\circ} \mathrm{C}\right)^{\mathrm{c}}$ & n.a. & n.a. & n.a. & n.a. & 19.40 & 18.90 & 8.20 & 20.08 & 19.20 & 7.85 & 20.50 & 18.65 & 7.10 \\
\hline $\begin{array}{l}\text { Biological parameters } \\
\text { Chlorophyll a }\left(\mathrm{mg} \cdot \mathrm{m}^{-3}\right)^{\mathrm{b}}\end{array}$ & n.a. & $1.62 \pm 1.91$ & $\begin{array}{l}1.04 \pm \\
0.91\end{array}$ & $\begin{array}{l}1.11 \pm \\
0.90\end{array}$ & n.a. & n.a. & n.a. & n.a. & n.a. & n.a. & $\begin{array}{l}5.35 \pm \\
3.28\end{array}$ & $\begin{array}{l}2.39 \pm \\
1.41\end{array}$ & $\begin{array}{l}0.80 \pm \\
0.37\end{array}$ \\
\hline Chlorophyll a $\left(\mathrm{mg} \cdot \mathrm{m}^{-3}\right)^{\mathrm{c}}$ & n.a. & n.a. & n.a. & n.a. & 2.58 & 1.65 & 0.62 & 2.83 & 3.43 & 1.045 & 2.35 & 1.72 & 1.12 \\
\hline Condition index ${ }^{d}$ & n.a. & $\begin{array}{l}31.85 \pm \\
5.43\end{array}$ & $\begin{array}{l}23.90 \pm \\
1.42\end{array}$ & $\begin{array}{l}17.15 \pm \\
1.42\end{array}$ & $\begin{array}{l}55.19 \pm \\
1.63\end{array}$ & $\begin{array}{l}30.74 \pm \\
3.27\end{array}$ & $\begin{array}{l}17.52 \pm \\
0.94\end{array}$ & $\begin{array}{l}40.17 \pm \\
1.49\end{array}$ & $\begin{array}{l}19.22 \pm \\
1.93\end{array}$ & $\begin{array}{l}16.73 \pm \\
2.42\end{array}$ & $\begin{array}{l}42.93 \pm \\
3.02\end{array}$ & n.a. & $\begin{array}{l}19.71 \pm \\
1.94\end{array}$ \\
\hline
\end{tabular}

n.a. not available

Mean values adapted from 2003 to 2007 data of the website "Site Ifremer consacré à l'environnement littoral": http://www.ifremer.fr/envlit/.

${ }^{b}$ Mean values \pm SD adapted from 2000 to 2004 data of the website "Site Ifremer consacré à l'environnement littoral": http://www.ifremer.fr/envlit/.

Mean values of 2008, collected by the French network Razlec (Ifremer, http://www.ifremer.fr/lerpc/reseaux/hydro/resul hydro.htm). Values correspond to the mean of July, September and December of 2008 of two measurements carried out per month at the bottom and at the top of the water surface from $\mathrm{Cl}$ and sites near C2 and C3.

${ }^{\mathrm{d}}$ Condition index from juvenile oysters was calculated by the method of Lobel and Wright (1982), and expressed in mg dry flesh weight/g dry shell weight 